\title{
Mononuclear and Binuclear Cyclopentadienyl Oxo Molybdenum and Tungsten Complexes: Syntheses and Applications in Olefin Epoxidation Catalysis
}

Ana M. Martins ${ }^{1 *}$, Carlos C. Romão ${ }^{2 *}$, Marta Abrantes $^{2}$, M. Cristina Azevedo ${ }^{1}$, Jinlan Cui $^{1}$, Alberto R. Dias ${ }^{1}$, M. Teresa Duarte ${ }^{1}$, M. Amélia Lemos ${ }^{3}$, Tiago Lourenço ${ }^{2}$ and Rinaldo Poli ${ }^{4}$

${ }^{1}$ Centro de Química Estrutural, Instituto Superior Técnico, Av. Rovisco Pais $n^{o} 1$, 1049-001 Lisboa, Portugal. E-mail: ana.martins@ist.utl.pt

${ }^{2}$ Instituto de Tecnologia Química e Biológica da Universidade Nova de Lisboa, Av. da República, Apt. 127, 2781-901 Oeiras, Portugal.

${ }^{3}$ Centro de Engenharia Biológica e Química, Instituto Superior Técnico, Av. Rovisco Pais, 1, 1049-001 Lisboa, Portugal.

${ }^{4}$ Laboratoire de Chimie de Coordination, 205 Route de Narbonne, 31077 Toulouse Cedex, France.

\begin{abstract}
New half-sandwich molybdenum complexes $\left[\mathrm{Mo}(\mathrm{CpBz}) \mathrm{Cl}_{2}(\mathrm{O})\right] \quad$ (1), $\left[\left\{\mathrm{Mo}(\mathrm{CpBz})(\mathrm{O})_{2}\right\}_{2}(\mu-\mathrm{O})\right](5)$ and $\left[\mathrm{Mo}(\mathrm{CpBz}) \mathrm{Cl}_{2}\right]_{2}(\mathbf{6})\left(\mathrm{CpBz}=\mathrm{C}_{5}\left(\mathrm{CH}_{2} \mathrm{Ph}\right)_{5}\right)$, the tungsten derivative $\left[\mathrm{W}(\mathrm{CpBz}) \mathrm{Cl}(\mathrm{O})_{2}\right]$ (3) and a high yield synthesis of $\left[\mathrm{Mo}(\mathrm{CpBz}) \mathrm{Cl}(\mathrm{O})_{2}\right](2)$, are described. The molecular structures and cyclic voltammetry measurements of $\mathbf{1}$ and $\mathbf{2}$ and a comparative study of various molybdenum dioxo complexes as olefin epoxidation catalyst precursors are also presented. The performance of $\left[\mathrm{Mo}\left(\mathrm{CpPr}_{4}^{\mathrm{i}}\right) \mathrm{Cl}(\mathrm{O})_{2}\right](\mathbf{9})$ as cyclooctene epoxidation catalyst using TBHP as oxidant
\end{abstract}


was determined and compared with other $\left[\mathrm{MoCp}{ }^{\prime} \mathrm{Cl}(\mathrm{O})_{2}\right]$ complexes $\left(\mathrm{Cp}^{\prime}=\mathrm{C}_{5} \mathrm{H}_{5}(\mathbf{7})\right.$, $\left.\mathrm{C}_{5} \mathrm{Me}_{5}(\mathbf{8}), \mathrm{CpBz}(\mathbf{2})\right)$ to assess the activity dependence on the ring-substituents. Under the same experimental conditions, bimetallic compounds $\left[\left\{\mathrm{MoCp}(\mathrm{O})_{2}\right\}_{2}(\mu-\mathrm{O})\right]\left(\mathrm{Cp}^{\prime}=\right.$ $\left.\mathrm{CpBz}(\mathbf{5}), \mathrm{Cp}^{*}(\mathbf{1 0}), \mathrm{CpBu}_{3}^{\mathrm{t}}(\mathbf{1 1}), \mathrm{CpPr}_{4}^{\mathrm{i}}(\mathbf{1 2})\right)$ have been tested and $\left[\mathrm{CpMoO}_{2}\right]_{2} \mathrm{O}$ was checked in aqueous solution, with $\mathrm{H}_{2} \mathrm{O}_{2}$ and TBHP as oxidant. Finally, $\left[\mathrm{Mo}(\mathrm{CpBz})(\mathrm{CO})_{3} \mathrm{CH}_{3}\right](4)$ was used as a catalyst precursor for cyclooctene epoxidation in the presence of TBHP. The analogy between the behaviors displayed by this complex and complex 2 is discussed.

Keywords: molybdenum, tungsten, pentabenzylcyclopentadienyl, oxo complexes, epoxidation, catalysis.

\section{Introduction}

Metal oxo and dioxo complexes are important catalysts of oxygen transfer reactions. Molybdenum and tungsten complexes, in particular, have been studied as models of oxotransferases active sites ${ }^{1}$ and played an important role in homogenous industrial catalysis through the olefin epoxidation ARCO and Halcon processes in the late 1960s. Recently, some of us have been exploring several aspects of Mo and $\mathrm{W}$ dioxide chemistry including: i) a range of inorganic and organometallic catalysts for olefin and sulfide oxidation with ${ }^{\mathrm{t}} \mathrm{BuOOH}(\mathrm{TBHP})^{2 ; 3 ; 4}$ and, in one case, with $\mathrm{H}_{2} \mathrm{O}_{2}{ }^{5}$ b) new synthetic pathways to the organometallic $\mathrm{Cp}$ ' $\mathrm{Mo}(\mathrm{O})_{2} \mathrm{X}$ derivatives; ${ }^{2 ; 6}$ iii) the aqueous chemistry of $\mathrm{Cp}{ }^{\prime} \mathrm{Mo}(\mathrm{O})_{2} \mathrm{X}$ and $\left[\mathrm{Cp}^{\prime} \mathrm{Mo}(\mathrm{O})_{2}\right]_{2}$ complexes. ${ }^{7}$ The later topics are particularly interesting since they offer the possibility of extending the usually versatile catalytic potencial of organometallic complexes to aqueous media, a central concern of "green chemistry". 
Since the pioneering studies on $\mathrm{CpMo}(\mathrm{O})_{2} \mathrm{X}$ and related complexes led by Malcolm

Green, ${ }^{8 ; 9}$ the synthesis of organometallic oxides has improved substantially. ${ }^{10 ; 11}$

Recently, very mild synthetic routes led to high yields of a number of $\mathrm{Cp}$ ' $\mathrm{Mo}(\mathrm{O})_{2} \mathrm{X}$ and $\left[\mathrm{Cp}{ }^{\prime} \mathrm{Mo}(\mathrm{O})_{2}\right]_{2}$ complexes where the substituents on Cp' vary from $\mathrm{H}$ to very bulky groups, e.g., ${ }^{\mathrm{i}} \mathrm{Pr},{ }^{\mathrm{t}} \mathrm{Bu}, \mathrm{CH}_{2} \mathrm{Ph}^{2 ; 6}\left[\mathrm{Cp}{ }^{\prime} \mathrm{Mo}(\mathrm{O})_{2} \mathrm{Cl}\right]\left(\mathrm{Cp}^{\prime}=\mathrm{C}_{5} \mathrm{H}_{5}, \mathrm{C}_{5} \mathrm{Me}_{5}\right.$ and $\left.\mathrm{C}_{5}\left(\mathrm{CH}_{2} \mathrm{Ph}\right)_{5}\right)$ have been tested as olefin epoxidation catalysts with TBHP. ${ }^{2 ; 12}$ The catalyst performance has been shown to depend on the cyclopentadienyl ligand and $\left[\mathrm{Mo}(\mathrm{CpBz}) \mathrm{O}_{2} \mathrm{Cl}\right]\left(\mathrm{CpBz}=\mathrm{C}_{5}\left(\mathrm{CH}_{2} \mathrm{Ph}\right)_{5}\right)$ led simultaneously to the most active and most stable catalytic system, when activated by ${ }^{\mathrm{t}} \mathrm{BuOOH}$.

In this work we present yet another synthetic method of high oxidation state pentabenzylcyclopentadienyl molybdenum and tungsten complexes, their structures and the results obtained on the catalytic epoxidation of olefins with several differently substituted $\mathrm{Cp} \mathrm{p}^{\prime} \mathrm{Mo}(\mathrm{O})_{2} \mathrm{X}$ and $\left[\mathrm{Cp} \mathrm{p}^{\prime} \mathrm{Mo}(\mathrm{O})_{2}\right]_{2}$ complexes with both TBHP and $\mathrm{H}_{2} \mathrm{O}_{2}$.

\section{Results and Discussion}

Synthetic and structural studies

As represented in Scheme 1, the readily accessible $\eta^{2}$-acyl complex $\left[\mathrm{Mo}(\mathrm{CpBz}) \mathrm{Cl}_{3}\left(\mathrm{COCH}_{3}\right)\right]^{13}$ proved to be a convenient starting material for the high yield synthesis of molybdenum oxo complexes. Treatment of $\left[\mathrm{Mo}(\mathrm{CpBz}) \mathrm{Cl}_{3}\left(\mathrm{COCH}_{3}\right)\right]$ with 1 equiv of ${ }^{\mathrm{t}} \mathrm{BuOOH}([\mathrm{Mo}]: \mathrm{ROOH}=1: 0.5)$ in $\mathrm{CH}_{2} \mathrm{Cl}_{2}$ led to $\left[\mathrm{Mo}(\mathrm{CpBz}) \mathrm{Cl}_{2}(\mathrm{O})\right](\mathbf{1})$ in $86 \%$ yield, whereas the same reaction carried out in the presence of an excess of ${ }^{t} \mathrm{BuOOH}$ gave $\left[\mathrm{Mo}(\mathrm{CpBz}) \mathrm{Cl}(\mathrm{O})_{2}\right](2)$ in $73 \%$ yield. The analogous tungsten complex, $\left[\mathrm{W}(\mathrm{CpBz}) \mathrm{Cl}(\mathrm{O})_{2}\right](3)$ was prepared in $43 \%$ yield by treatment of $\left[\mathrm{W}(\mathrm{CpBz}) \mathrm{Cl}_{4}\right]{ }^{13}$ with an excess of ${ }^{\mathrm{t}} \mathrm{BuOOH}($ Scheme 1$)$. Taking as reference $\left[\mathrm{Mo}(\mathrm{CO})_{6}\right]$, which is the starting material for the preparation of [Mo( $\left.\mathrm{CpBz}) \mathrm{Cl}_{3}\left(\mathrm{COCH}_{3}\right)\right]$, the global yields of $\mathbf{1}$ and $\mathbf{2}$ 
are respectively, $66 \%$ and $56 \%$ that are much higher than the yields reported in the literature for other cyclopentadienyl molybdenum oxo complexes. ${ }^{2 ; 8 ; 11 ; 12}$ The yield obtained for $\mathbf{3}$, although less significant than that of $\mathbf{2}$, also corresponds to a major increase when compared to $\left[\mathrm{WCp} *(\mathrm{O})_{2} \mathrm{Cl}\right] .{ }^{10}$

Scheme 1

The ${ }^{1} \mathrm{H}$ NMR spectra of complexes $\mathbf{2}$ and $\mathbf{3}$ show singlets for the methylenic benzyl protons and the usual 2:2:1 patterns for the benzyl aromatic protons of the pentabenzylcyclopentadienyl ligand, indicating that there are no constrains to the free rotation of the benzyl groups. The $\mathrm{M}=\mathrm{O}$ moieties are readily identified by the IR spectra that show characteristic bands at $941 \mathrm{~cm}^{-1}$ for $\mathbf{1}$, at 918 and $889 \mathrm{~cm}^{-1}$ for 2 and at 944 and $903 \mathrm{~cm}^{-1}$ for 3 .

Treatment of $\left[\mathrm{Mo}(\mathrm{CpBz})(\mathrm{CO})_{3} \mathrm{CH}_{3}\right](4){ }^{13}$ with an excess of ${ }^{\mathrm{t}} \mathrm{BuOOH}$ led to $\left[\left\{\mathrm{Mo}(\mathrm{CpBz})(\mathrm{O})_{2}\right\}_{2}(\mu-\mathrm{O})\right](\mathbf{5})$ in $35 \%$ yield. The IR spectrum of $\mathbf{5}$ shows terminal $\mathrm{Mo}=\mathrm{O}$ stretching peaks at 914 and $886 \mathrm{~cm}^{-1}$ and a bridging $\mathrm{Mo}-\mathrm{O}-\mathrm{Mo}$ band at $775 \mathrm{~cm}^{-}$

1. These values are identical to those reported for $\left[\left\{\mathrm{MoCp}{ }^{\prime}(\mathrm{O})_{2}\right\}_{2}(\mu-\mathrm{O})\right]\left(\mathrm{Cp}^{\prime}=\mathrm{C}_{5} \mathrm{H}_{5}\right.$, $\left.\mathrm{C}_{5} \mathrm{Me}_{5}\right)^{8 ; 10}$ and are consistent with a linear Mo-O-Mo arrangement, as characterized by X-ray diffraction for $\left[\left\{\operatorname{MoCp} *(O)_{2}\right\}_{2}(\mu-O)\right]$. The proton and carbon NMR spectra of 5 display only one set of resonances for the pentabenzylcyclopentadienyl ligands, consistent with average $\mathrm{C}_{\mathrm{s}}$ symmetry.

Alkylation reactions of $\mathbf{1}$ and $\mathbf{2}$ were attempted using AllylMgBr and $\mathrm{ZnMe}_{2}$, respectively. Treatment of $\mathbf{1}$ with 2 equiv of AllylMgBr led to a diamagnetic microcrystalline yellow solid. ${ }^{1} \mathrm{H}$ and ${ }^{13} \mathrm{C}$ NMR spectra of this complex show one set of $\mathrm{CpBz}$ resonances and elemental analysis is consistent with the formulation 
$\left[\mathrm{Mo}(\mathrm{CpBz}) \mathrm{Cl}_{2}\right]_{2}(\mathbf{6})$. The formation of $\mathbf{6}$ excludes the occurrence of chloride metathesis and suggests that the attack of the Grignard reagent takes place through electrophilic abstraction of the oxo ligand by magnesium resulting in metal reduction. Three different types of molecular structures have been determined by X-ray diffraction for related $\left[\mathrm{MCp}^{\prime} \mathrm{Cl}_{2}\right]_{2}(\mathrm{M}=\mathrm{Mo}, \mathrm{W}) \cdot{ }^{14}$ In all cases, the existence of metal-metal bonds accounts for the diamagnetism of those $\mathrm{M}(\mathrm{III})$ derivatives. Attempts to ascertain the molecular structure of $\mathbf{6}$ failed due to the small size of the crystals.

Reactions of 2 with $\mathrm{ZnMe}_{2}$ did not give the foreseen methyl derivative and also did not allow the characterization of any reaction product.

Attempts to prepare cationic complexes were carried on by reacting $\mathbf{2}$ with chloride abstractors as $\mathrm{TlPF}_{6}$ and $\mathrm{AgPF}_{6}$ in $\mathrm{CH}_{2} \mathrm{Cl}_{2}$, in the presence or absence of xylyl isocyanide. Precipitation of a blue material, which was not identified, was observed regardless of the conditions used.

The molecular structures of $\left[\mathrm{Mo}(\mathrm{CpBz})(\mathrm{O}) \mathrm{Cl}_{2}\right], \mathbf{1}$ and $\left[\mathrm{Mo}(\mathrm{CpBz})(\mathrm{O})_{2} \mathrm{Cl}\right], \mathbf{2}$ have been determined by X-ray diffraction. Relevant bond lengths and angles are presented in Table 1 and Figures 1 and 2 depict ORTEP representations of the complexes with the corresponding atomic labelling scheme.

Table 1

Figure 1

Figure 2 
In complexes $\left[\mathrm{M}(\mathrm{CpBz})(\mathrm{O}) \mathrm{Cl}_{2}\right], \mathbf{1}$, and $\left[\mathrm{M}(\mathrm{CpBz})(\mathrm{O})_{2} \mathrm{Cl}\right], \mathbf{2}$, the metal adopts a three-legged piano-stool geometry with the basal angles $\mathrm{X}-\mathrm{Mo}(1)-\mathrm{Y}(\mathrm{X}, \mathrm{Y}=\mathrm{O}(1)$, $\mathrm{Cl}(1), \mathrm{Cl}(2)$ and $\mathrm{O}(2))$ ranging from $92.12(7)$ to $108.94(14)^{\circ}$ for $\mathbf{1}$ and $100.41(14)$ to109.0(2) for $\mathbf{2}$, smaller than the angles defined with the $\mathrm{CpBz}$ centroid that range from 114.29(5) to 116.85(14) in compound $\mathbf{1}$ and 111.80(7) to 116.014(13) in complex 2 (see Table 1). In both compounds the phenyl rings of four benzyl fragments are directed opposite to the metal and one is bent down towards the metal although sufficiently far apart to prevent any bonding interaction. Also in both complexes the $\mathrm{Cp}$ ring is practically parallel to the planes defined by the three basal atoms, the dihedral angle being 6.4(3) for 1 and 4.7(4) ${ }^{\circ}$ for complex 2 . The Mo atom is closer to the basal plane than to the $\mathrm{Cp}(0.892(2) / 2.058(2)$ and $0.805(2) / 2.085(3) \AA$ respectively for $\mathbf{1}$ and $\mathbf{2})$. To better characterize the relative conformation of the phenyl rings we present in Table1 the torsion angles of the pending benzyl arms (defined as $\mathrm{M}-\mathrm{C}\left(\mathrm{CpBz}\right.$ ring) $-\mathrm{C}\left(\mathrm{CH}_{2}\right.$ bridge $-\mathrm{C}$ (first $\mathrm{C}$ atom of the $\mathrm{Ph}$ ring). In both compounds the longest $\mathrm{Mo}-\mathrm{C}$ bonds reflect the trans effect due to the oxo ligands and therefore the Mo-C distances in the dioxo complex are, in average, longer than in $\mathbf{1}$. In compound $\mathbf{1}$ the $\mathrm{Mo}-\mathrm{Cl}$ distances are in average longer than the $\mathrm{Mo}-\mathrm{Cl}$ distance in compound 2, whereas the $\mathrm{Mo}-\mathrm{O}$ distance is relatively shorter in $\mathbf{1}$. The $\mathrm{Mo-} \mathrm{Cl}$ distances in compound $\mathbf{1}$ are, on average, slightly longer than those of $\mathrm{CpMoOCl}_{2}[2.297(3)$ and 2.306(3) $\AA],{ }^{15}$ but slightly shorter than those of $\mathrm{Cp}^{*} \mathrm{MoOCl}_{2}\left[2.3260(8)\right.$ and 2.3420(7) $\AA$ ].$^{11}$ This phenomenon seems better consistent with an electronic effect than with a steric one, since $\mathrm{Cp} *$ is less sterically encumbering but more electron releasing than $\mathrm{CpBz}$. The Mo-O distance of $\mathbf{1}$ is, on the other hand, longer than that observed for the Cp* analogue [1.683(2) $\AA]$ and closer to that reported for the $\mathrm{Cp}$ analogue $[1.740(6) \AA$ A $]$. These distances should be treated with great caution, because of the possible presence of $\mathrm{O}$ in the $\mathrm{Cl}$ site, and 
viceversa. Given that the co-crystallization of small amounts of $\mathbf{2}$ into the crystals of $\mathbf{1}$ (and viceversa) have been absolutely excluded on the basis of the spectroscopic analyses, there exists always the possibility of positional disorder between the $\mathrm{O}$ and $\mathrm{Cl}$ positions. Partial $\mathrm{O}$ occupancy in the $\mathrm{Cl}$ site would render the $\mathrm{Mo}-\mathrm{Cl}$ distance artificially shorter, whereas partial $\mathrm{Cl}$ occyupancy in the $\mathrm{O}$ site renders renders the Mo$\mathrm{O}$ distance artificially longer. This argument suggests that the $\mathrm{Cp} * \mathrm{MoCl}_{2} \mathrm{O}$ structure, with shorter Mo-O and longer Mo-Cl distances, is probably less affected by potential disorder problems, although it does not represent positive proof of disorder for the other structures. For compound 2, the Mo-Cl distance is much shorter than in compound $\left(\mathrm{C}_{5} \mathrm{HPr}_{4}^{\mathrm{i}}\right) \mathrm{MoOCl}_{2}[2.3251(7) \AA$ ] , which appears to be the only other well determined structure for a $\mathrm{Cp}$ ' $\mathrm{MoO}_{2} \mathrm{Cl}$ compound. ${ }^{6}$ Compound $\mathrm{Cp} * \mathrm{MoO}_{2} \mathrm{Cl}$ was also crystallographically characterized, but an orientational disorder prevented the accurate determination of the bonding parameters. ${ }^{10}$ On the other hand, the Mo-O distances of 2 are relatively long compared to $\left(\mathrm{C}_{5} \mathrm{HPr}_{4}^{\mathrm{i}}\right) \mathrm{MoOCl}_{2}[1.700(2)$ and $1.720(2) \AA]$. The latter are even slightly shorter than that measured for $\mathbf{1}$, as would be expected given the smaller radius associated with the higher oxidation state. This argument, once again, tends to suggest the potential presence of positional disorder in the $\mathrm{O}$ and $\mathrm{Cl}$ positions for the determined crystal structure of $\mathbf{2}$. Short intramolecular hydrogen interactions are observed in complex 1 between the oxo ligand and the hydrogen atom $\mathrm{H}(16)$, that is in the phenyl ortho position of the benzyl group that bends towards the metal, and the hydrogen atoms $\mathrm{H}(501)$ and $\mathrm{H}(502)$ that are the methylenic protons of a benzyl substituent $(\mathrm{O}(1) \cdots \mathrm{H}(16), 2.781(7) \AA ̊ \AA \mathrm{O}(1) \cdots \mathrm{H}(501) /(502), 2.893(7) / 2.990(7) \AA)$.

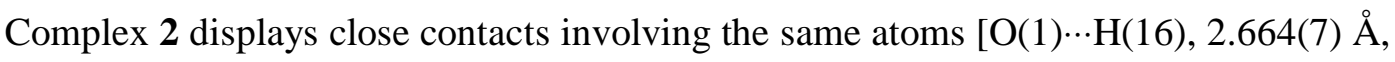
$\mathrm{O}(1) \cdots(502), 2.630(7) \AA)$. Moreover, $\mathrm{O}(2)$ also interacts with one of the hydrogen atom of another methylenic benzyl group, $\mathrm{O}(2) \cdots \mathrm{H}(201), 2.616(7) \AA$ A. Although these 
interactions are too week to be observed by NMR in solution, it is relevant to mention that related intramolecular bonds have been characterized by Thiel and co-workers ${ }^{16}$ and also that an intramolecular interaction between an oxo ligand and the ${ }^{t} \mathrm{BuOOH}$ proton is proposed as a key step in the activation of tert-butylhydroperoxide by molybdenum epoxidation catalysts. ${ }^{3 ; 17}$

The redox behavior of molybdenum oxo complexes has attracted much attention owing to its relevance to the oxygen atom transfer catalyzed by molybdenum enzymes. ${ }^{1}$ In general, complexes with the $\left[\mathrm{Mo}^{\mathrm{V}}=\mathrm{O}\right]$ core exhibit a reversible reduction that has been assigned to the $\mathrm{Mo}(\mathrm{V}) / \mathrm{Mo}(\mathrm{IV})$ pair. This behavior is also displayed in the $\mathrm{CV}$ of $\left[\mathrm{Mo}(\mathrm{CpBz})(\mathrm{O}) \mathrm{Cl}_{2}\right]$ that shows a reversible reduction at $\mathrm{E}_{1 / 2}^{\mathrm{red}}=-1.012 \mathrm{~V}$ in $\mathrm{THF}(\mathrm{vs}$. $\mathrm{Fc}^{+} / \mathrm{Fc}$ ). The anodic process is irreversible with a half-wave potential of $0.995 \mathrm{~V}$ (Table 2). The lack of electrochemical data for half-sandwich complexes of general type $\left[\mathrm{MCp}^{\prime}(\mathrm{O}) \mathrm{X}_{2}\right]\left(\mathrm{Cp}^{\prime}=\mathrm{Cp}\right.$ type ligand; $\mathrm{X}=$ anionic ligand $)$ compel us to compare our result with hexacoordinated complexes $\left[\mathrm{Mo}(\mathrm{L}) \mathrm{OCl}_{2}\right]$ where $\mathrm{L}$ represents tripodal scorpionate type monoanionic ligands as $(\mathrm{pz})_{3} \mathrm{BH}$ or $(\mathrm{pz})_{2} \mathrm{CHX}$ (X fragment containing $\mathrm{O}$ or $\mathrm{S}$ donors), in which $\mathrm{E}_{1 / 2}^{\text {red }}$ values range between 0.54 and $1.38 \mathrm{~V} .^{18 ; 19}$ The value encountered for 1 compares well with those of cis- $(-0.934 \mathrm{~V})$ and trans- $-\mathrm{LMoOCl}_{2}$ $(-1.15 \mathrm{~V})$ where $\mathrm{L}$ is the anion of $(\mathrm{pz})_{2} \mathrm{CH}\left\{(5-\mathrm{Me})\left(3-{ }^{\mathrm{t}} \mathrm{Bu}\right)(2-\mathrm{OH}) \mathrm{Ph}\right\} .{ }^{20}$ However, contrary to those compounds, but likewise most $\mathrm{Mo}(\mathrm{V})$ oxo complexes, the anodic process is irreversible, a result that accounts for the instability of mono-oxo Mo(VI) species that readily convert into $\left[\mathrm{MoO}_{2}\right]^{+}$through reaction with traces of water present in the medium.

Table 2 
The $\mathrm{CV}$ of $\left[\mathrm{Mo}(\mathrm{CpBz})(\mathrm{O})_{2} \mathrm{Cl}\right]$ shows an irreversible one-electron reduction peak, at $\mathrm{E}_{\mathrm{p}}^{\mathrm{ox}}$ $-1.378 \mathrm{~V} \mathrm{vs} \mathrm{Fc}^{+} / \mathrm{Fc}$ attributed to the $\mathrm{Mo}(\mathrm{VI}) / \mathrm{Mo}(\mathrm{V})$ redox couple, followed by a second reduction irreversible peak at $-1,670 \mathrm{~V}$ assigned to the $\mathrm{Mo}(\mathrm{V}) / \mathrm{Mo}(\mathrm{IV})$ process. These results are in conformity with $\mathrm{CV}$ results reported for dioxomolybdenum complexes and, accordingly to the irreversible character of these processes, increasing of scan rate causes a shift of the peaks to cathodic potentials and the current-function is approximately independent of the scan rates used. ${ }^{21 ; 22}$

\section{Catalysis studies on cyclooctene epoxidation}

Previous studies on the epoxidation of olefins carried out with $\mathrm{Cp}^{\prime} \mathrm{MoO}_{2} \mathrm{X}$ complexes as catalysts were only effective with TBHP as the terminal oxidant. A dependence on the bulk of the Cp' ring was also noted and the loss of activity of the $\mathrm{CpMoO}_{2} \mathrm{Cl}$ complex was attributed to the presence of water in the reaction medium, on the basis of

circumstantial proof. ${ }^{2}$ Later on some of us have established the stability of Cp*Mo-oxo species, derived from bimetallic compounds like $\left[\mathrm{Cp} * \mathrm{MoO}_{2}\right]_{2} \mathrm{O}$, in aqueous solution within a wide range of $\mathrm{pH}$ values. These studies started to unveil an extensive aqueous chemistry of cyclopentadienyl oxo complexes, namely that of the $\left[\mathrm{Cp} * \mathrm{MoO}_{2}\right]_{2} \mathrm{O}$. ${ }^{6 ; 7 ; 23}$ This kind of binuclear might be considered a special case of $\mathrm{Cp}^{\prime} \mathrm{MoO}_{2} \mathrm{X}(\mathrm{X}=$ $\left.\mathrm{Cp}^{\prime} \mathrm{MoO}_{3}\right]^{-}$) and has never been studied in epoxidation catalysis. This situation prompted the following prospective studies with a threefold aim: i) assess the activity dependence of $\mathrm{Cp}^{\prime} \mathrm{MoO}_{2} \mathrm{Cl}$ on the nature of the ring-substituents using TBHP as oxidant; ii) screen the catalytic activity of the bimetallic species $\left[\mathrm{Cp}^{\prime} \mathrm{MoO}_{2}\right]_{2} \mathrm{O}$ using TBHP as oxidant; iii) check for catalytic activity of $\left[\mathrm{Cp}^{\prime} \mathrm{MoO}_{2}\right]_{2} \mathrm{O}$ in aqueous solution with both $\mathrm{H}_{2} \mathrm{O}_{2}$ and TBHP as oxidant. 
Questions i) and ii) were addressed only by carrying out experiments in non-aqueous solutions $\left(\mathrm{CHCl}_{3}\right.$ as solvent), at $55^{\circ} \mathrm{C}$ with $1 \%$ catalyst, cyclooctene as olefin and TBHP as terminal oxidant (see experimental part for details). These conditions have been systematically used in our previous studies to allow for a better comparison of the catalytic performance of different molecular systems all operating through activation of TBHP by the $\mathrm{Mo}(\mathrm{VI}) \mathrm{O}_{2}$ fragment. Blank reactions showed that no significant amount of epoxide was formed in the absence of catalyst. The values measured for cyclooctene conversion to its epoxide as a function of time, are given in Table 3 for mononuclear $\mathrm{Cp} \mathrm{MoO}_{2} \mathrm{Cl}$ and binuclear $\left[\mathrm{Cp}^{\prime} \mathrm{MoO}_{2}\right]_{2} \mathrm{O}$ catalysts. No significant formation of byproducts (e.g. diol from epoxide ring opening) other than epoxide was observed. As can be seen, from these results, the mononuclear complexes $\mathrm{Cp}^{\prime} \mathrm{MoO}_{2} \mathrm{Cl}$ are clearly faster in the early stages of the reaction. In particular, $(\mathrm{CpBz}) \mathrm{MoO}_{2} \mathrm{Cl}(2)$ and $\mathrm{CpMoO}_{2} \mathrm{Cl}$ (7) attain rather high conversions already at ca. 5 min reaction time: $60.8 \%$ and $75.6 \%$ respectively. After $3.5 \mathrm{~h}$ both catalysts achieved $100 \%$ conversion. $\mathrm{Cp}\left({ }^{\mathrm{i}} \mathrm{Pr}\right)_{4} \mathrm{MoO}_{2} \mathrm{Cl}(\mathbf{9})$ has a comparatively slow start but rapidly overtakes the performance of $\mathrm{Cp}^{*} \mathrm{MoO}_{2} \mathrm{Cl}(\mathbf{8})$ that becomes almost inactive after $1.5 \mathrm{~h}$. After $24 \mathrm{~h}$ the conversion achieved with 9 largely exceeds that of $\mathbf{8}$. The tricarbonyl $\mathbf{4}$ was used as plausible catalyst precursor for $\mathrm{CpBzMoO}_{2} \mathrm{Me}$ in a similar way to the formation of $\mathrm{Cp}^{\prime} \mathrm{MoO}_{2} \mathrm{Cl}$ from $\mathrm{Cp}{ }^{\prime} \mathrm{Mo}(\mathrm{CO})_{3} \mathrm{Cl}$. ${ }^{2 ; 24}$ A conversion of $82.2 \%$ was obtained within the first 30 minutes. However, in contrast to 7, this value did not further increase. It seems evident that the catalyst decomposed under the reaction conditions.

Table 3 
Under the same operating conditions the bimetallic compounds achieve conversions in the same range as the monomers 8 and $\mathbf{9}$. In contrast to the corresponding monomer, the $\mathrm{C}_{5} \mathrm{Bz}_{5}$ derivative, $\left[(\mathrm{CpBz}) \mathrm{MoO}_{2}\right]_{2} \mathrm{O}(5)$ is the least performing of all the compounds tested. Conversely, at $24 \mathrm{~h}$ reaction time, $\left[\mathrm{Cp}^{\mathrm{i}} \mathrm{Pr}_{4} \mathrm{MoO}_{2}\right]_{2} \mathrm{O}(\mathbf{1 2})$ outperforms all others complexes tested, except 2 and 7. Both 12 and $\left[\mathrm{Cp} * \mathrm{MoO}_{2}\right]_{2} \mathrm{O}(\mathbf{1 0})$ achieve higher conversions at 24 than their mononuclear congeners.

Figure 3 shows the time dependence curve of this reaction for the monometallic catalysts, which is typical for all other $\mathrm{MoO}_{2} \mathrm{X}_{2} \mathrm{~L}_{2}$-type catalysts tested so far. There is no observable induction period or a clear indication that the original catalyst is transformed into another species, in agreement with previous NMR observations by Bergman and Trost for epoxidation with $\mathbf{8} .{ }^{12}$ Kinetic and spectroscopic studies on $\mathrm{MO}_{2} \mathrm{X}_{2} \mathrm{~L}_{2}(\mathrm{M}=\mathrm{Mo}, \mathrm{W})$ complexes indicate that the catalyst initially activates TBHP to form an intermediate that transfers one $\mathrm{O}$ atom to the olefin. ${ }^{3}$ The kinetic model for these reactions explains the slowing down of the reaction as the result of the increasing amount of ${ }^{t} \mathrm{BuOH}$ formed, which competes with TBHP for coordination positions at the metal, thereby blocking the TBHP activation step. Given the coordination and electronic similarity between $\mathrm{MO}_{2} \mathrm{X}_{2} \mathrm{~L}_{2}$ and $\mathrm{Cp}^{\prime} \mathrm{MoO}_{2} \mathrm{X}$ complexes, we believe that the latter follow a similar reaction pathway in their olefin epoxidation catalysis.

Figure 3

The corresponding profile for the binuclear compounds, Figure 4 shows a slower start and a slow progression of the reaction after $c a$. $2 \mathrm{~h}$. This retardation of the reaction is noted at the same time that an off-white precipitate starts to separate slowly from the initially homogeneous solution. These precipitates, named 10a, 11a and 12a from the 
reactions of $\mathbf{1 0}, \mathbf{1 1}$ and $\mathbf{1 2}$, respectively, are not formed in the reactions of mononuclear $\mathrm{Cp}^{\prime} \mathrm{MoO}_{2} \mathrm{Cl}$. The reaction profiles in Figure 4 clearly show this pronounced inhibition of the reaction velocity. However, the reaction does not stop, and can lead to high conversions at $24 \mathrm{~h}$, as noted above. The precipitates 10a, 11a and 12a isolated and washed at the end of the reaction were reused as heterogeneous catalysts on a second run, under similar initial conditions. In all cases the conversion after $24 \mathrm{~h}$ was essentially the same of the first run, started with the respective homogeneous solution of the bimetallic complexes $\mathbf{1 0}, \mathbf{1 1}$ and $\mathbf{1 2}$. This means that these insoluble species are also an active, slow, yet resistant catalyst for COE epoxidation. It should also be noted that the supernatant solutions obtained after separation of 10a, 11a and 12a are still active for COE epoxidation upon addition of another charge of both COE and TBHP. Since the quantification of the results was problematic they are not shown on a quantitative basis.

Figure 4

The identification of the molecular nature of the precipitates was attempted only with 10a. Its IR spectrum shows the presence of $\mathrm{Cp}^{*}\left(2963.5 \mathrm{~cm}^{-1}\right)$. However, it does not reveal any terminal $\mathrm{M}=\mathrm{O}$ stretch and a band at $804 \mathrm{~cm}^{-1}$ seems to be too low for a typical O-O bond in a Mo peroxo complex. The insolubility of the compound in organic solvents prevented NMR studies. Therefore, full characterization of this product and its analogues is still under way namely via solid state spectroscopic and analytical methods.

In order to study the activity of these systems in aqueous solution $\mathrm{H}_{2} \mathrm{O}_{2}$ and TBHP were used as oxidants in COE epoxidation. Complex $\mathbf{1 0}$ was tested with $30 \% \mathrm{H}_{2} \mathrm{O}_{2}$ both at 
the natural $\mathrm{pH}$ of its solution and at $\mathrm{pH} 1.5$. After 4 hours, the conversions were around $2 \%$ in both cases. On the contrary, both $\mathbf{8}$ and $\mathbf{1 0}$ catalyzed COE epoxidation in aqueous 70\% TBHP. After 4 hours the conversion was around $27 \%$ for $\mathbf{1 0}$ and $37 \%$ for the monomer $\mathbf{8}$. No attempts have been made to optimize these reaction conditions because our first aim in these exploratory studies was to establish whether water was deleterious for the catalytic system and whether $\mathrm{H}_{2} \mathrm{O}_{2}$ is capable of been used as terminal oxidant. The results confirm that the catalysts are still active in water solution but only when TBHP is used as oxidant. In agreement with previous observations $\mathrm{H}_{2} \mathrm{O}_{2}$ is unable to be activated to olefin epoxidation by octahedral or pseudo-octahedral $\mathrm{MoO}_{2} \mathrm{X}_{2} \mathrm{~L}_{2}$ or $\mathrm{Cp} \mathrm{MoO}_{2} \mathrm{X}$ complexes.

\section{Discussion}

As already stated, the catalytic reaction profile of $\mathrm{Cp}^{\prime} \mathrm{MoO}_{2} \mathrm{X}$ complexes (Figure 3) fits entirely to the one already described at length for other (isoelectronic) $\mathrm{MoO}_{2} \mathrm{X}_{2} \mathrm{~L}_{2}$. This mechanism invokes a t-butylperoxide intermediate that is the catalytically active species for oxygen transfer to the olefin. This picture was first proposed by Chong and Sharpless for the catalyst precursor $\mathrm{MoO}_{2}(\mathrm{acac})_{2}{ }^{25}$ as well as by Trost and Bergman for $\mathrm{Cp} * \mathrm{MoO}_{2} \mathrm{Cl}^{12}$ Both authors ruled out peroxo complexes as catalytic intermediates in their systems with the TBHP oxidant. Moreover, isolated $\mathrm{Cp} * \mathrm{MoO}\left(\mathrm{O}_{2}\right) \mathrm{Cl}$ was shown to be inactive. This t-butylperoxide intermediate leads to a rather sterically crowded coordination sphere. Such crowding creates a difficulty in explaining the order of activity that can be qualitatively extracted from the early reaction times in Figure $3, \mathrm{Cp}$ $\sim \mathrm{C}_{5} \mathrm{Bz}_{5} \gg \mathrm{C}_{5} \mathrm{Me}_{5} \sim \mathrm{C}_{5} \mathrm{H}^{\mathrm{i}} \mathrm{Pr}_{4}$. An alternative electronic explanation for this order could be based either on the ability of the Cp' ligands to undergo ring-slippage (or distortion) that might alleviate the steric pressure of the intermediate, or on the electronic richness 
of the terminal oxo ligands. The former argument is in line with a recent report where enhanced catalytic action is achieved by loss of one ancillary ligand. ${ }^{26}$ Presently we have no kinetic or spectroscopic data $\left({ }^{17} \mathrm{O}\right.$ NMR $)$ that might confirm any of these hypotheses. However, DFT modulation of the interaction of $\mathrm{Cp}^{\prime} \mathrm{MoO}_{2} \mathrm{X}$ complexes with TBHP is presently under study and might shed some light on this question. Nevertheless, the steric argument is in accord with the fact that the mononuclear species are more active than the binuclear ones. In the latter $\mathrm{X}$ is formally replaced by the very bulky $\left[\mathrm{Cp}^{\prime} \mathrm{MoO}_{3}\right]^{-}$. This effect has its higher instance in the case of $\mathrm{Cp}^{\prime}=\mathrm{C}_{5} \mathrm{Bz}_{5}$ which is the least active of the bimetallic compounds. In other words, sterics makes it difficult to have both metals centers operating simultaneously. However, this may not be decisive in their catalytic performance since they transform into an insoluble, catalytically active species. The understanding of the nature of such species is necessary to clarify the mode of action of the bimetallic compounds and is in progress.

The present studies also meet our expectation that $\mathrm{Cp}^{\prime} \mathrm{MoO}_{2} \mathrm{X}$ complexes are catalytically active in aqueous solution provided TBHP is used instead of $\mathrm{H}_{2} \mathrm{O}_{2}$. Indeed, the $\mathrm{Cp} * \mathrm{MoO}_{2}$ (VI) fragment survives a wide range of $\mathrm{pH}$ conditions in aqueous solution where species like $\left[\mathrm{Cp} * \mathrm{MoO}_{2}\left(\mathrm{H}_{2} \mathrm{O}\right)\right]^{+},\left[\mathrm{Cp} * \mathrm{MoO}_{2}(\mathrm{OH})\right]$ and $\left[\mathrm{Cp} * \mathrm{MoO}_{3}\right]^{-}$have been identified. ${ }^{23}$ Their cis- $\mathrm{MoO}_{2}$ moiety is expected to form a peroxo complex with $\mathrm{H}_{2} \mathrm{O}_{2}$. Whichever such peroxo complex may be, it is now clear that it is incapable of epoxidizing olefins, even in acidic medium, as has been shown for many other Mo-oxoperoxo complexes. ${ }^{12 ; 25 ; 27}$

On the other hand, this cis- $\mathrm{MoO}_{2}$ moiety is capable of activating TBHP to produce a catalytically active species. We believe that such activation results from the direct interaction of TBHP with the $\mathrm{Cp}^{\prime} \mathrm{MoO}_{2} \mathrm{X}$ complex. However, TBHP is also capable of originating peroxo complexes from cis- $\mathrm{MoO}_{2}$ fragments. Some studies have shown that 
these peroxo complexes may become active in the presence of excess TBHP, ${ }^{26 ; 27}$ although this doesn't seem to be the case in the $\mathrm{Cp}^{\prime} \mathrm{MoO}_{2} \mathrm{X}$ system. ${ }^{12}$ Nevertheless, both versions of this mechanism of TBHP activation remain to be clarified and warrant further study

\section{Conclusions}

The synthesis of $\mathrm{Cp}^{\prime} \mathrm{MO}_{2} \mathrm{Cl}(\mathrm{M}=\mathrm{Mo}, \mathrm{W})$ derivatives can be performed from several $\mathrm{Cp}^{\prime} \mathrm{MX}_{\mathrm{n}}$ precursors upon direct reaction with ${ }^{\mathrm{t}} \mathrm{BuOOH}$ under very mild conditions and with high yields. These compounds, together with bimetallic complexes of the type $\left[\mathrm{Cp}^{\prime} \mathrm{MoO}_{2}\right]_{2} \mathrm{O}$ were tested as catalysts for olefin epoxidation with both ${ }^{\mathrm{t}} \mathrm{BuOOH}$ and $\mathrm{H}_{2} \mathrm{O}_{2}$ as terminal oxidants. Although it is obvious that the nature of the substitutents on the $\mathrm{Cp}$ ' ring strongly influences the overall performance of the catalysts, both in terms of initial activity rates but more importantly, in terms of their long term performance at $24 \mathrm{~h}$ reaction, steric bulk is not the decisive parameter to control this dependence. The bimetallic complexes $\left[\mathrm{Cp}^{\prime} \mathrm{MoO}_{2}\right]_{2} \mathrm{O}$ produce higher yields at long reaction times than their monomeric $\mathrm{Cp}^{\prime} \mathrm{MoO}_{2} \mathrm{Cl}$ counterparts. However, they decompose during the reaction to form an insoluble catalytically active species still unidentified. $\left[\mathrm{Cp}^{\prime} \mathrm{MoO}_{2}\right]_{2} \mathrm{O}$ and $\mathrm{Cp}^{\prime} \mathrm{MoO}_{2} \mathrm{Cl}$ are active in aqueous solution with TBHP but not with $\mathrm{H}_{2} \mathrm{O}_{2}$ as an oxidant. Theoretical and experimental studies aiming at clarifying the mechanistic issues raised are in progress.

\section{Experimental Section}

General Procedures. All manipulations were carried out under a dry nitrogen atmosphere with standard Schlenk techniques except those where $\mathrm{O}_{2}$ from air was used as an oxidant. Solvents were predried and distilled from the following drying agents: 
hexane and dichloromethane $\left(\mathrm{CaH}_{2}\right), \mathrm{d}_{6}$-benzene and diethyl ether $(\mathrm{Na})$. Literature methods were used to prepare $\mathrm{HCpBz},{ }^{28}\left[\mathrm{Mo}(\mathrm{CpBz}) \mathrm{Cl}_{3}\left(\eta^{2}-\mathrm{COCH}_{3}\right)\right],\left[\mathrm{W}(\mathrm{CpBz}) \mathrm{Cl}_{4}\right]$, $\left[\mathrm{Mo}(\mathrm{CpBz})(\mathrm{CO})_{3} \mathrm{CH}_{3}\right],{ }^{13}$ and $\mathrm{Cp}^{*}{ }_{2} \mathrm{Mo}_{2} \mathrm{O}_{5}, \quad\left(\mathrm{C}_{5} \mathrm{HPr}_{4}^{\mathrm{i}}\right)_{2} \mathrm{Mo}_{2} \mathrm{O}_{5}, \quad\left(\mathrm{C}_{5} \mathrm{H}_{2} \mathrm{Bu}_{3}^{\mathrm{t}}\right)_{2} \mathrm{Mo}_{2} \mathrm{O}_{5}$, $\left(\mathrm{C}_{5} \mathrm{HPr}_{4}^{\mathrm{i}}\right) \mathrm{MoO}_{2} \mathrm{Cl}^{6}{ }^{6} \mathrm{NMR}$ spectra were recorded on a Varian Unity 300 instrument at room temperature and were referred to the residual ${ }^{1} \mathrm{H}$ and ${ }^{13} \mathrm{C}$ NMR solvents resonances. Infrared spectra were recorded using $\mathrm{KBr}$ pellets on a Jasco FT/IR 430. Mass spectra were recorded on a Finnegan MAT System 8200 spectrometer, except that of complex 5 that was obtained by a Fourier transform ion cyclotron resonance mass spectrometer (Finnegan FT/MS 2001-DT spectrometer), equipped with a 3 Tesla superconducting magnet. Elemental analyses were obtained from the Laboratório de Análises do IST (Fisons Instrument 1108). Cyclic voltammetry measurements were carried out using a Radiometer DEA 101 Digital Electrochemical Analyser interfaced with an IMT 102 Electrochemical Interface. $\left[\mathrm{Bu}_{4} \mathrm{~N}\right]\left[\mathrm{BF}_{4}\right]$ (Fluka, electrochemical grade) was used as supporting electrolyte in THF with concentration $c a .10^{-1} \mathrm{M}$. All experiments were performed with concentrations of complexes in the range $4.2-4.8 \times 10^{-}$

${ }^{3}$ M. All potentials were referenced to the ferrocene/ferrocenium couple as internal standard with $\mathrm{E}_{1 / 2}=0.50 \mathrm{~V}$ versus SCE. A Pt disc (with $\phi=1 \mathrm{~mm}$ ) was used as working electrode. All experiments were carried out at $25^{\circ} \mathrm{C}$ in the absence of oxygen.

$\left[\mathrm{Mo}(\mathbf{C p B z})(\mathbf{O}) \mathbf{C l}_{2}\right](\mathbf{1})$. A solution of $\left[\mathrm{Mo}(\mathrm{CpBz}) \mathrm{Cl}_{3}\left(\eta^{2}-\mathrm{COCH}_{3}\right)\right](0.66 \mathrm{~g}, 0.86 \mathrm{mmol})$ in dichloromethane was treated with a $5.5 \mathrm{M}$ solution of tert-butylhydroperoxide in $n$-decane $(0.08 \mathrm{~mL}, 0.44 \mathrm{mmol})$. After 1.5 hours at room temperature, the reaction mixture was evaporated to dryness and the oily product formed was extracted in diethyl ether. The filtered solution was concentrated and cooled overnight at $-20{ }^{\circ} \mathrm{C}$ leading to the formation of yellow crystals that were separated by filtration. Yield $0.52 \mathrm{~g}(0.74$ 
mmol, 86\%). IR (KBr): $v(\mathrm{Mo}=\mathrm{O}), \mathrm{cm}^{-1}:$ 941(s). Anal. calcd. for $\mathrm{C}_{40} \mathrm{H}_{35} \mathrm{Cl}_{2} \mathrm{OMo}$ : $\mathrm{C}$ 68.78; H 5.05. Found: C 68.74; H 5.15.

$\left[\mathrm{Mo}(\mathbf{C p B z})(\mathbf{O})_{2} \mathbf{C l}\right]$ (2). A $5.5 \mathrm{M}$ tert-butylhydroperoxide solution in $n$-decane $(0.78$ $\mathrm{mL}, 4.26 \mathrm{mmol})$ was added dropwise to a solution of $\left[\mathrm{Mo}(\mathrm{CpBz}) \mathrm{Cl}_{3}\left(\eta^{2}-\mathrm{COCH}_{3}\right)\right](1.08$ $\mathrm{g}, 1.42 \mathrm{mmol}$ ) in dichloromethane. The mixture was stirred at room temperature during 12 hours until the solution turned yellow. The reaction was stopped by the addition of manganese dioxide. The solution was filtered off and the solvent removed under vacuum to dryness. The solid obtained was washed with cold hexane and extracted in diethyl ether. Cooling at $-20{ }^{\circ} \mathrm{C}$ gave 2 as a yellow crystalline solid. Yield, $0.70 \mathrm{~g}, 1.03$ mmol, $73 \% .{ }^{1} \mathrm{H}$ NMR $\left(\mathrm{C}_{6} \mathrm{D}_{6}\right): \delta 6.76\left(\mathrm{~m}, 15 \mathrm{H}, m-\mathrm{C}_{6} H_{5}, p-\mathrm{C}_{6} H_{5}\right), 6.46(\mathrm{~d}, 10 \mathrm{H}$, $\left.o-\mathrm{C}_{6} H_{5}\right), 3.86\left(\mathrm{~s}, 10 \mathrm{H}, \mathrm{CH}_{2} \mathrm{Ph}\right) .{ }^{13} \mathrm{C}\left\{{ }^{1} \mathrm{H}\right\} \quad \mathrm{NMR}\left(\mathrm{C}_{6} \mathrm{D}_{6}\right): \delta 137.8\left(i-C_{6} \mathrm{H}_{5}\right), 129.3$ $\left(C_{5}\left(\mathrm{CH}_{2} \mathrm{Ph}\right)_{5}\right), 129.2\left(o-C_{6} \mathrm{H}_{5}\right), 128.5\left(m-C_{6} \mathrm{H}_{5}\right), 126.6\left(p-C_{6} \mathrm{H}_{5}\right), 33.0\left(C \mathrm{H}_{2} \mathrm{Ph}\right) . \mathrm{IR}$ $(\mathrm{KBr}), \mathrm{cm}^{-1}: \quad 918(\mathrm{vs}), 889(\mathrm{vs}), \mathrm{v}(\mathrm{Mo}=\mathrm{O}) ; \quad 586(\mathrm{~s}), \mathrm{v}(\mathrm{O}=\mathrm{Mo}=\mathrm{O})$. Anal. calcd. for $\mathrm{C}_{40} \mathrm{H}_{35} \mathrm{ClO}_{2} \mathrm{Mo:} \mathrm{C} 70.57$; H 5.19. Found: C 70.12; H 5.22.

$\left[\mathbf{W}(\mathbf{C p B z})(\mathbf{O})_{2} \mathbf{C l}\right](3) . \quad$ A solution of $\left[\mathrm{W}(\mathrm{CpBz}) \mathrm{Cl}_{4}\right](0.50 \mathrm{~g}, 0.60 \mathrm{mmol})$ in dichloromethane was treated with an excess of a $5.5 \mathrm{M}$ solution of tert-butylhydroperoxide in $n$-decane at room temperature. The excess of tert-butylhydroperoxide was destroyed after stirring for $12 \mathrm{~h}$ by addition of manganese dioxide. The solution was filtered off and the solvent was removed to dryness under vacuum. The residue was washed with cold hexane $(2 \times 3 \mathrm{~mL})$ and extracted in diethyl ether. Green crystals of 3 formed at $-20{ }^{\circ} \mathrm{C}$ from the $\mathrm{Et}_{2} \mathrm{O}$ solution. Yield, $0.20 \mathrm{~g}, 43 \%$. ${ }^{1} \mathrm{H}$ NMR $\left(\mathrm{C}_{6} \mathrm{D}_{6}\right): \delta 6.76\left(\mathrm{~m}, 15 \mathrm{H}, m-\mathrm{C}_{6} \mathrm{H}_{5}, p-\mathrm{C}_{6} \mathrm{H}_{5}\right), 6.46\left(\mathrm{~d}, 10 \mathrm{H}, o-\mathrm{C}_{6} \mathrm{H}_{5}\right), 3.95(\mathrm{~s}$, $\left.10 \mathrm{H}, \mathrm{C} H_{2} \mathrm{Ph}\right) .{ }^{13} \mathrm{C}\left\{{ }^{1} \mathrm{H}\right\}$ NMR $\left(\mathrm{C}_{6} \mathrm{D}_{6}\right): \delta 137.9\left(i-C_{6} \mathrm{H}_{5}\right), 129.5\left(C_{5}\left(\mathrm{CH}_{2} \mathrm{Ph}\right)_{5}\right), 129.2$ $\left(o-C_{6} \mathrm{H}_{5}\right), 128.5\left(m-C_{6} \mathrm{H}_{5}\right), 126.6\left(p-C_{6} \mathrm{H}_{5}\right), 32.9\left(C \mathrm{H}_{2} \mathrm{Ph}\right) . \mathrm{IR}(\mathrm{KBr}): \mathrm{v}(\mathrm{W}=\mathrm{O}), \mathrm{cm}^{-1}$ : 
944(vs), 903(vs). Anal. Calcd. for $\mathrm{C}_{40} \mathrm{H}_{35} \mathrm{ClO}_{2} \mathrm{~W}$ : C 62.64; $\mathrm{H}$ 4.60. Found: $\mathrm{C}$ 62.55; $\mathrm{H}$ 4.74 .

$\left[\mathrm{Mo}(\mathbf{C p B z})(\mathbf{O})_{2}\right]_{2}(\boldsymbol{\mu}-\mathbf{O})(\mathbf{5})$. Excess of a $5.5 \mathrm{M}$ solution of tert-butylhydroperoxide solution in $n$-decane was added dropwise to a solution of $\left[\mathrm{Mo}(\mathrm{CpBz})(\mathrm{CO})_{3} \mathrm{CH}_{3}\right](3.55$ $\mathrm{g}, 5.0 \mathrm{mmol}$ ) in dichloromethane. The mixture was stirred at room temperature during 5 $\mathrm{h}$ and manganese dioxide was added to destroy the excess of tert-butylhydroperoxide. The solids were removed by filtration and the solvent was evaporated to dryness under vacuum. The residue was washed with cold hexane $(2 \times 3 \mathrm{~mL})$, extracted in diethyl ether and filtered. Cooling at $-20{ }^{\circ} \mathrm{C}$ led to the separation of yellow crystals of $\mathbf{5}$ in 35 $\%$ yield (2.28 g). ${ }^{1} \mathrm{H}$ NMR $\left(\mathrm{C}_{6} \mathrm{D}_{6}\right): \delta 6.83\left(\mathrm{~m}, 15 \mathrm{H}, m-\mathrm{C}_{6} \mathrm{H}_{5}, p-\mathrm{C}_{6} \mathrm{H}_{5}\right), 6.68(\mathrm{~m}, 10 \mathrm{H}$, $\left.o-\mathrm{C}_{6} \mathrm{H}_{5}\right), 4.27\left(\mathrm{~s}, 10 \mathrm{H}, \mathrm{C} H_{2} \mathrm{Ph}\right) .{ }^{13} \mathrm{C}\left\{{ }^{1} \mathrm{H}\right\} \quad \mathrm{NMR}\left(\mathrm{C}_{6} \mathrm{D}_{6}\right): \delta 138.6\left(i-C_{6} \mathrm{H}_{5}\right), 129.5$ $\left(o-C_{6} \mathrm{H}_{5}\right), 128.6\left(m-C_{6} \mathrm{H}_{5}\right), 126.5\left(p-C_{6} \mathrm{H}_{5}\right), 125.6\left(\mathrm{C}_{5}\left(\mathrm{CH}_{2} \mathrm{Ph}\right)_{5}\right), 32.8\left(C_{2} \mathrm{Ph}\right) . \mathrm{IR}$ $(\mathrm{KBr}): \mathrm{v}(\mathrm{Mo}=\mathrm{O}), \mathrm{cm}^{-1}:$ 914(vs), 886(s); v(Mo-O-Mo), $\mathrm{cm}^{-1}:$ 775(vs). MS: 791, $\left[\left\{(\mathrm{CpBz}) \mathrm{Mo}_{2} \mathrm{O}_{5}\right\}^{-}\right] ;$661, [\{(CpBz) $\left.\left.\mathrm{MoO}_{3}\right\}^{-}\right] ; 644,\left[\left\{(\mathrm{CpBz}) \mathrm{MoO}_{2}\right\}^{-}\right] ; 515, \mathrm{CpBz}$. Anal. calcd. for $\mathrm{C}_{80} \mathrm{H}_{70} \mathrm{O}_{5} \mathrm{Mo}$ : C 73.73; H, 5.41. Found: C 74.00; H 5.46.

\section{X-ray diffraction experimental determination}

Crystal structures were obtained using a MACH3 Nonius diffractometer equipped with Mo radiation $(\lambda=0.71069 \AA)$ for the two compounds. Experimental details of the crystal structure determination and refinement are given in Table 3.

All data were corrected for Lorentz, polarization and long term intensity fluctuations. Absorption effects in compound $\mathbf{1}$ were corrected using semi empirical psi-scans [ref A], no absorption correction was performed in compound 2. Structures were solved by direct methods using SIR99 ${ }^{29}$ and refined by full-matrix least squares against $F^{2}$ using SHELXTL ${ }^{30}$ all included in the suit of programs WinGX v1.64.05 for windows. ${ }^{31}$ 
In both structures all non-hydrogen atoms were refined anisotropically and the hydrogen atoms were inserted in idealized positions riding in the parent $\mathrm{C}$ atom.

More experimental details are given in the Supplementary Material. Illustrations of the molecular structures were made with ORTEP3. ${ }^{32}$ Data was deposited in CCDC under the deposit numbers CCDC 256118 and 256119 for compounds 1 and $\mathbf{2}$ respectively.

\section{Catalytic experiments}

Catalytic epoxidation of cyclooctene was performed under nitrogen atmosphere in a reaction vessel equipped with a magnetic stirrer and immersed in a thermostated oil bath. A $1 \%$ molar ratio of catalyst/substrate $(73 \mu \mathrm{mol}$ complex and $0,8 \mathrm{~g}, 7.3 \mathrm{mmol}$ cyclooctene) and a substrate/oxidant (2,64 mL, tert-butyl hydroperoxide (TBHP), 5.5 M in decane) ratio of 0.5 were used, with $0,8 \mathrm{~g}$ of $n$-dibutyl ether (internal standard) and 3 $\mathrm{mL}$ dried chloroform as solvent. The solution was stirred for $24 \mathrm{~h}$ at $55^{\circ} \mathrm{C}$ and the course of the reaction was monitored by quantitative GC analysis. Samples were taken every $30 \mathrm{~min}$ and diluted with dichloromethane. For the destruction of the peroxide a small amount of manganese dioxide was added and the resulting slurry was filtered over a Pasteur pipette with cotton and silica and the filtrate was injected on a gas chromatograph (Thermofinnigan Trace 2000 GC) equipped with a J\&W capillary column (Cyclosilb, $30 \mathrm{~m} * 0.25 \mathrm{~mm} * 0.25 \mu \mathrm{m}$ ) and a flame ionization detector. In order to recycle the catalyst, the reaction medium was filtered, washed with dichloromethane and $n$-hexane and the precipitate was recharged with $n$-dibutyl ether, cyclooctene, tertbutyl hydroperoxide and chloroform as solvent in the original quantities and submitted to the catalytic process under the conditions performed in the first run. A single sample was taken after $24 \mathrm{~h}$ of reaction. 
The catalytic epoxidation of cyclooctene with hydrogen peroxide was performed by adding 1,5 mL of a $30 \% \mathrm{wt}$. solution of hydrogen peroxide in water to the substrate, internal standard and catalyst. The 0.5 ratio of substrate/oxidant was maintained. After 4 $\mathrm{h}$ of stirring at $55^{\circ} \mathrm{C}$ the reaction was stopped by the addition of manganese dioxide and magnesium sulphate for the destruction of hydrogen peroxide and removal of water. After the gas evolution ceased the slurry was filtered over a Pasteur pipette with cotton and silica, the filtrate was extracted with $4 \times 25 \mathrm{~mL}$ of dichloromethane and injected in the GC column. Similarly, the catalytic epoxidation of cyclooctene with TBHP/water as oxidant was performed adding $2,1 \mathrm{~mL}$ of a $70 \%$ wt. solution of tert-butyl hydroperoxide in water to the catalyst, substrate and internal standard solution. After $4 \mathrm{~h}$ of stirring at $55^{\circ} \mathrm{C}$, the reaction was stopped with the addition of manganese dioxide for the destruction of peroxides. After the gas evolution ceased, the slurry was filtered and extracted with $4 \times 25 \mathrm{~mL}$ of dichloromethane and injected in the GC column.

The catalytic experiments performed in acidic media were done by adding $1,5 \mathrm{~mL}$ of a $30 \%$ wt. solution of hydrogen peroxide in $3 \mathrm{~mL}$ water and adding a concentrated solution of sulphuric acid until the $\mathrm{pH}$ reached 1.5. This solution was then added to the reaction vessel containing the substrate, internal standard and catalyst and stirred for $4 \mathrm{~h}$ at $55^{\circ} \mathrm{C}$. The reaction was stopped by the addition of manganese dioxide and magnesium sulphate for the destruction of hydrogen peroxide and removal of water. After the gas evolution ceased the slurry was filtered over a Pasteur pipette with cotton and silica, the filtrate was extracted with $4 \times 25 \mathrm{~mL}$ of dichloromethane and injected in the GC column.

The conversion of cyclooctene oxide in all the experiments was calculated from a calibration curve recorded prior to the reaction course. 


\section{Acknowledgements}

We are grateful to Fundação para a Ciência e a Tecnologia, Portugal, for funding (POCTI/QUI/34400/2000 and SFRH/BPD/3590/2000) and Dr. M. Conceição Oliveira for performing the MS of complex 5. RP acknowledges funding from the European Commission through the AQUACHEM Research Training Network (Contract $\mathrm{n}^{\circ}$ MRTN-CT-2003-503864). 


\section{References}

(1) Enemark, J. H.; Cooney, J. J. A.; Wang, J.-J.; Holm, R. H. Chem. Rev. 2004, 104, 1175.

(2) Abrabtes, M.; Santos, A. M.; Mink, J.; Kühn, F. E.; Romão, C. C.

Organometallics 2003, 22, 2112.

(3) Kühn, F. E.; Groarke, M.; Bencze, E.; Herdtweck, E.; Prazeres, A.; Santos, A. M.; Calhorda, M. J.; Romão, C. C.; Gonçalves, I. S.; Lopes, A. D.; Pillinger, M. Chem. Eur. J. 2002, 8, 2370.

(4) Abrantes, M.; Valente, A. A.; Pillinger, M.; Gonçalves, I. S.; Rocha, J.; Romão, C. C. Chem. Eur. J. 2003, 9, 2685.

(5) Abrantes, M.; Valente, A. A.; Pillinger, M.; Gonçalves, I. S.; Rocha, J.; Romão, C. C. J. Catal. 2002, 209, 237.

(6) Saurenz, D.; Demirhan, F.; Richard, P.; Poli, R.; Sitzmann, H. Eur. J. Inorg. Chem. 2002,1415.

(7) Poli, R. Eur. J. Inorg. Chem. 2004, 10, 332.

(8) Cousins, M.; Green, M. L. H. J. Chem. Soc. 1964, 1567.

(9) Bunker, M. J.; Cian, A. D.; Green, M. L. H. J. Chem. Soc., Chem. Commun. $1977,59$.

(10) Faller, J. W.; Ma, Y. J. Organomet. Chem 1988, 340, 59.

(11) Bottomley, F.; Boyle, P. D.; Chen, J. Organometallics 1994, 13, 370.

(12) Trost, M. K.; Bergman, R. G. Organometallics 1991, 10, 1172.

(13) Martins, A. M.; Branquinho, R.; Cui, J.; Dias, A. R.; Duarte, M. T.; Fernandes, J.; Rodrigues, S. S. J. Organomet. Chem. 2004, 689, 2368.

(14) Poli, R. Chem. Rev. 1991, 91, 509.

(15) Bottomley, F.; Ferris, E. C.; White, P. S. Organometallics 1990, 9, 1166. 
(16) Glas, H.; Spiegler, M.; Thiel, W. R. Eur. J. Inorg. Chem. 1998, 275.

(17) Herrmann, W. A.; Haider, J. J.; Fridgen, J.; Lobmaier, G. M.; Spiegler, M. J. Organomet. Chem. 2000, 603, 69.

(18) Cleland Jr., W. E.; Barnhart, K. M.; Yamanouchi, K.; Collison, D.; Mabbs, F. E.; Ortega, R. B.; Enemark, J. H. Inorg. Chem. 1987, 26, 1017.

(19) Carrano, C. J.; Chohan, B. S.; Hammes, B. S.; Kail, B. W.; Nemykin, V. N.; Basu, P. Inorg. Chem. 2003, 42, 5999.

(20) Kail, B.; Nemykin, V. N.; Davie, S. R.; Carrano, C. J.; Hammes, B.; Basu, P. J. Am. Chem. Soc. 2002, 41, 1281.

(21) Bustos, C.; Burckhardt, O.; Schrebler, R.; Carrillo, D.; Arif, A. M.; Cowley, A. H.; Nunn, C. M. Inorg. Chem. 1990, 29, 3996.

(22) Dinda, R.; Sengupta, P.; Ghosh, S.; Sheldrick, W. S. Eur. J. Inorg. Chem. 2003, 363.

(23) Poli, R. Chem. Eur. J. 2004, 10, 332.

(24) Zhao, J.; Santos, A. M.; Herdtweck, E.; Kuhn, F. E. J. Mol. Cat.(A) 2004, 222, 265.

(25) Chong, A. O.; Sharpless, K. B. J. Org. Chem. 1977, 42, 1587.

(26) Brito, J. A.; Gomez, M.; Muller, G.; Teruel, H.; Clinet, J. C.; Dunach, E.; Maestro, M. A. Eur. J. Inorg. Chem. 2004, 4728.

(27) Thiel, W. R.; Priermeier, T. Angew. Chem., Int. Ed. Engl. 1995, 34, 1737.

(28) Bueno, C.; Churchill, M. R. Inorg. Chem. 1981, 20, 2197.

(29) Altomare, A.; Burla, M. C.; Camalli, M.; Cascarano, G.; Giacovazzo, C.; Guagliardi, A.; Moliterni, A. G. G.; Polidori, G.; Spagna, R. J. Appl. Cryst. 1999, 32, 115. 
(30) Sheldrick, G. M. SHELXL-97, A computer program for refinement of crystal structures, 1997, University of Göttigen.

(31) Farrugia, L. J.; Wing X. J. Appl. Cryst. 1999, 32, 837.

(32) Farrugia, L. J. J. Appl. Cryst. 1997, 30, 565. 
Scheme 1
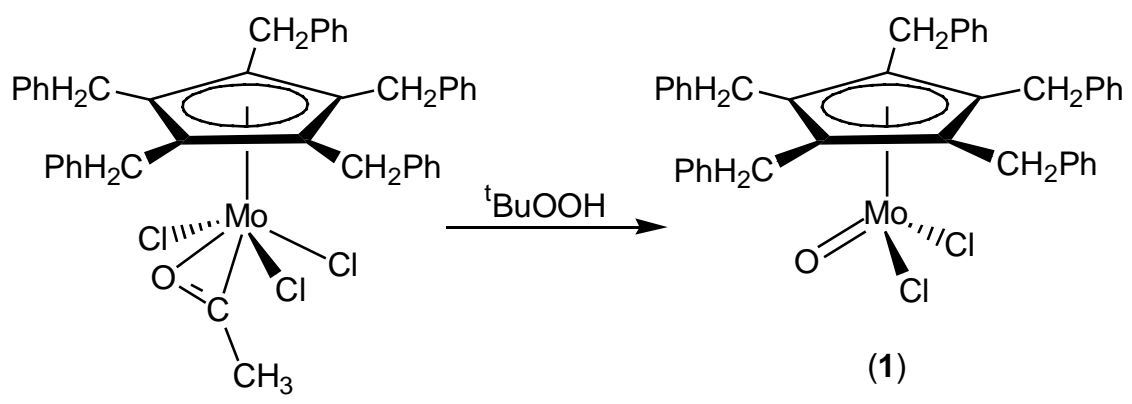

(1)
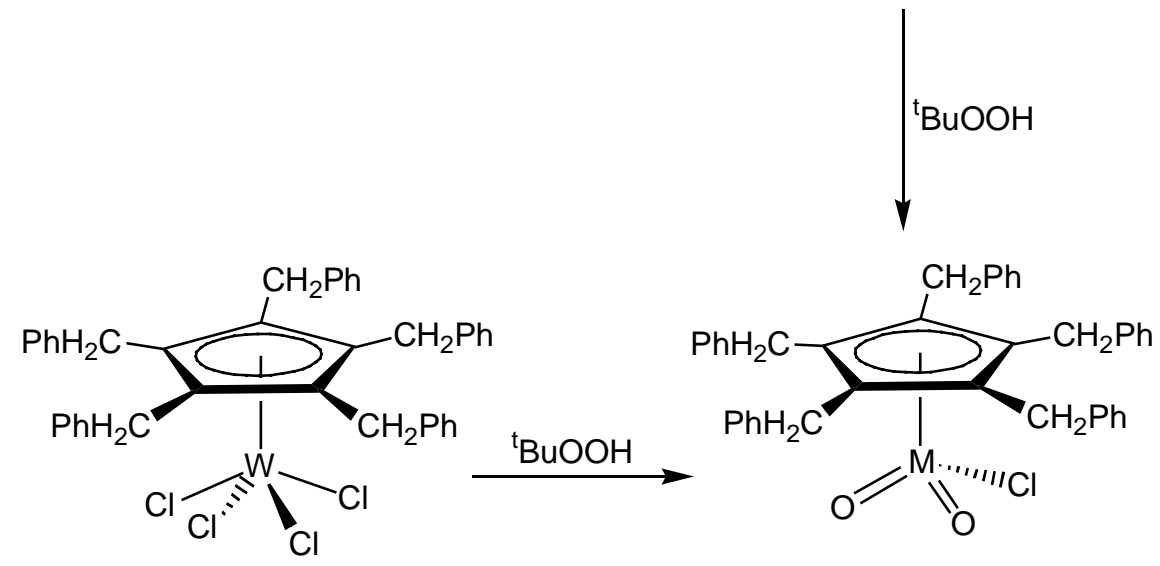

$$
\begin{aligned}
& M=M o,(2) \\
& M=W,(3)
\end{aligned}
$$


Figures and Tables Captions

Figure 1. Molecular structure of 1. $\mathrm{H}$ atoms were excluded for clarity. Thermal ellipsoids at $30 \%$ probability level.

Figure 2. Molecular structure of 2. H atoms were excluded for clarity. Thermal ellipsoids at $30 \%$ probability level.

Figure 3. Reaction conditions: Olefin: Cyclooctene; Temp: $55^{\circ} \mathrm{C}$; Oxid: TBHP; Cat: $1 \% \mathrm{Cp}^{\prime} \mathrm{MoO}_{2} \mathrm{Cl}$; Solvent: $\mathrm{CHCl}_{3}$

Figure 4. Reaction conditions: Olefin: Cyclooctene; Temp: $55^{\circ} \mathrm{C}$; Oxid: TBHP; Cat: $1 \%\left[\mathrm{Cp}^{\prime} \mathrm{MoO}_{2}\right]_{2} \mathrm{O} ;$ Solvent: $\mathrm{CHCl}_{3}$.

Table 1. Relevant bond distances and angles for compounds $\mathbf{1}$ and $\mathbf{2}$.

Table 2. Electrochemical data for complexes $\mathbf{1}$ e $\mathbf{2}^{\mathrm{a}}$.

Table 3. Conversion (\%) of cyclooctene to its epoxide in $\mathrm{CHCl}_{3}$ solution at $55^{\circ} \mathrm{C}$ with TBHP catalyzed by $\mathrm{Cp}^{\prime} \mathrm{MoO}_{2} \mathrm{X}$ and related complexes.

Table 4. Experimental details on X-ray data collection and structure refinement. 
Table 1

\begin{tabular}{|c|c|c|}
\hline & $\lceil\mathrm{Mo}(\mathrm{CpBz})(\mathrm{O}) \mathrm{Cl},\rceil_{,} \mathbf{1}$ & $\left\lceil\mathrm{Mo}(\mathrm{CpBz})(\mathrm{O})_{2} \mathrm{Cll}, 2\right.$ \\
\hline $\mathrm{M}-\mathrm{Cl}(1)$ & $2.3078(18)$ & $2.282(2)$ \\
\hline $\mathrm{M}-\mathrm{Cl}(2)$ & $2.3349(18)$ & \\
\hline $\mathrm{M}-\mathrm{O}(1)$ & $1.735(4)$ & $1.891(4)$ \\
\hline $\mathrm{M}-\mathrm{O}(2)$ & & $1.748(5)$ \\
\hline $\mathrm{M}-\mathrm{CT}$ & $2.0600(7)$ & $2.0894(10)$ \\
\hline $\mathrm{Cl}(1)-\mathrm{M}-\mathrm{Cl}(2)$ & $92.12(7)$ & \\
\hline $\mathrm{Cl}(1)-\mathrm{M}-\mathrm{O}(1)$ & $108.94(14)$ & $100.32(14)$ \\
\hline $\mathrm{Cl}(2)-\mathrm{M}-\mathrm{O}(1)$ & $105.71(15)$ & \\
\hline $\mathrm{Cl}(1)-\mathrm{M}-\mathrm{O}(2)$ & & $102.1(2)$ \\
\hline $\mathrm{O}(1)-\mathrm{M}-\mathrm{O}(2)$ & & $109.0(2)$ \\
\hline $\mathrm{CT}-\mathrm{M}-\mathrm{Cl}(1)$ & $115.89(5)$ & $111.80(7)$ \\
\hline $\mathrm{CT}-\mathrm{M}-\mathrm{Cl}(2)$ & $114.29(5)$ & \\
\hline CT-M-O(1) & $116.85(14)$ & $116.04(13)$ \\
\hline $\mathrm{CT}-\mathrm{M}-\mathrm{O}(2)$ & & $115.69(18)$ \\
\hline $\mathrm{M}-\mathrm{C}(1)-\mathrm{C}(10)-\mathrm{C}(11)$ & $-40.7(8)$ & $50.3(9)$ \\
\hline $\mathrm{M}-\mathrm{C}(2)-\mathrm{C}(20)-\mathrm{C}(21)$ & $161.8(4)$ & $-155.7(5)$ \\
\hline $\mathrm{M}-\mathrm{C}(3)-\mathrm{C}(30)-\mathrm{C}(31)$ & $153.5(4)$ & $177.6(5)$ \\
\hline $\mathrm{M}-\mathrm{C}(4)-\mathrm{C}(40)-\mathrm{C}(41)$ & $156.1(4)$ & $161.1(6)$ \\
\hline $\mathrm{M}-\mathrm{C}(5)-\mathrm{C}(50)-\mathrm{C}(51)$ & $167.5(4)$ & $155.9(5)$ \\
\hline
\end{tabular}

$\mathrm{CT}-\mathrm{CpBz}$ centroid 
Table 2

\begin{tabular}{c|c|c|c}
\hline Compound & $\mathrm{E}_{1 / 2}^{\text {red }}(\mathrm{V})$ & $\mathrm{E}_{\mathrm{p}}^{\text {red }}(\mathrm{V})$ & $\mathrm{E}_{\mathrm{p}}^{\mathrm{ox}}(\mathrm{V})$ \\
\hline $\mathrm{Mo}(\mathrm{CpBz})(\mathrm{O}) \mathrm{Cl}_{2}$ & -1.012 & & 0.995 (irr) \\
\hline $\mathrm{Mo}(\mathrm{CpBz})(\mathrm{O})_{2} \mathrm{Cl}$ & & -1.378 (irr) & \\
& & -1.670 (irr) & \\
\hline
\end{tabular}

${ }^{\mathrm{a}}$ Cyclic voltammetry in THF at $25^{\circ} \mathrm{C}: 3.6-4.8 \times 10^{-3} \mathrm{M}$ complex $; 10^{-1} \mathrm{M} \mathrm{Bu}_{4} \mathrm{NBF}_{4}$ supporting electrolyte; $10^{-3} \mathrm{M}$ ferrocene as internal standard. All potentials were evaluated at $200 \mathrm{mV} / \mathrm{s}$. 
Table 3

\begin{tabular}{|c|c|c|c|c|c|c|c|c|c|c|c|c|c|}
\hline Cp'ring in & \multicolumn{13}{|c|}{ Time (h) } \\
\hline $\mathrm{Cp}^{\prime} \mathrm{MoO}_{2} \mathrm{Cl}$ & 0.083 & 0.1 & 0.5 & 1.0 & 1.5 & 2.0 & 2.5 & 3.0 & 3.5 & 4.0 & 5.0 & 6.0 & 24 \\
\hline $\mathrm{C}_{5} \mathrm{Bz}_{5}(2)$ & 60.8 & & 79.3 & 84.5 & 93.1 & 94.8 & 96.6 & 98.3 & 100.0 & 100.0 & --- & --- & 100.0 \\
\hline $\mathrm{C}_{5} \mathrm{H}_{5}(7)$ & 75.6 & & 82.2 & 86.7 & 91.1 & 97.8 & 98.0 & 98.5 & 100.0 & 100.0 & --- & --- & 100.0 \\
\hline $\mathrm{C}_{5} \mathrm{Me}_{5}(\mathbf{8})$ & 38.0 & & 46.0 & 55.0 & 59.0 & 60.0 & 61.0 & 62.0 & 63.0 & 64.0 & --- & --- & 64.0 \\
\hline $\mathrm{C}_{5} \mathrm{H}^{\mathrm{i}} \mathrm{Pr}_{4}(\mathbf{9})$ & 6.2 & & 55.7 & 65.1 & 49.0 & 59.1 & --- & --- & --- & 67.0 & --- & 75.0 & 85.0 \\
\hline $\begin{array}{c}\left(\mathrm{C}_{5} \mathrm{Bz}_{5}\right) \mathrm{Mo}(\mathrm{CO})_{3} \mathrm{Me} \\
(\mathbf{4})\end{array}$ & & & 82.2 & & & & & & & & & & \\
\hline $\begin{array}{l}\text { Cp' ring in } \\
{\left[\mathrm{Cp}^{\prime} \mathrm{MoO}_{2}\right]_{2}}\end{array}$ & & & & & & & & & & & & & \\
\hline $\mathrm{C}_{5} \mathrm{Bz}_{5}(\mathbf{5})$ & & 0.7 & 21.4 & 45.1 & 36.3 & 50.2 & --- & 43.8 & --- & --- & 67.6 & 44.6 & 70.2 \\
\hline $\mathrm{C}_{5} \mathrm{Me}_{5}(\mathbf{1 0})$ & & 2.7 & 43.3 & --- & 46.3 & --- & --- & 51.4 & --- & 55.5 & 59.1 & 59.7 & 86.7 \\
\hline (10a) & & --- & --- & --- & --- & --- & --- & --- & --- & --- & --- & --- & 90.0 \\
\hline $\mathrm{C}_{5} \mathrm{H}_{2}{ }^{\mathrm{t}} \mathrm{Bu}_{3}(\mathbf{1 1})$ & & 3.5 & 69.3 & 67.0 & 74.3 & & --- & 75.0 & --- & 72.3 & 78.2 & 70.9 & 78.9 \\
\hline (11a) & & --- & --- & --- & --- & --- & --- & --- & --- & --- & --- & --- & 76.4 \\
\hline $\mathrm{C}_{5} \mathrm{H}^{\mathrm{i}} \operatorname{Pr}_{4}(\mathbf{1 2})$ & & 17.9 & 67.8 & 62.6 & 73.7 & 70.4 & --- & --- & --- & 74.5 & 82.7 & 85.1 & 99.9 \\
\hline (12a) & & --- & --- & --- & --- & --- & --- & --- & --- & --- & --- & --- & 100.0 \\
\hline
\end{tabular}


Table 4

\begin{tabular}{|c|c|c|}
\hline Compound & 1 & 2 \\
\hline Empirical formula & $\mathrm{C} 40 \mathrm{H} 35 \mathrm{Cl} 2 \mathrm{Mo} \mathrm{O}$ & $\mathrm{C} 40 \mathrm{H} 35 \mathrm{Cl} \mathrm{Mo} \mathrm{O} 2$ \\
\hline Formula weight & 698.52 & 679.07 \\
\hline Temperature & 293(2) K & 293(2) K \\
\hline Wavelength & $0.71069 \AA$ & $0.71069 \AA$ \\
\hline Crystal system & Monoclinic & Monoclinic \\
\hline Space group & $\mathrm{P} 21 / \mathrm{n}$ & $\mathrm{P} 21 / \mathrm{n}$ \\
\hline $\begin{array}{c}\text { Unit cell } \\
\text { dimensions }\end{array}$ & $\begin{array}{l}\mathrm{a}=13.335(4) \AA \\
\mathrm{b}=16.863(2) \AA \\
\mathrm{c}=15.241(2) \AA \\
\beta=100.456(16)^{\circ}\end{array}$ & $\begin{array}{l}\mathrm{a}=11.681(4) \AA \\
\mathrm{b}=14.790(4) \AA \\
\mathrm{c}=19.840(6) \AA \\
\beta=104.59(3)^{\circ}\end{array}$ \\
\hline Volume & $3370(2) \AA^{3}$ & $3316.9(18) \AA^{3}$ \\
\hline $\mathrm{Z}$ & 4 & 4 \\
\hline Calculated density & $1.377 \mathrm{Mg} / \mathrm{m}^{3}$ & $1.360 \mathrm{Mg} / \mathrm{m}^{3}$ \\
\hline Absorption coefficient & $0.578 \mathrm{~mm}^{-1}$ & $0.509 \mathrm{~mm}^{-1}$ \\
\hline $\mathrm{F}(000)$ & 1436 & 1400 \\
\hline Crystal size & $0.4 \times 0.25 \times 0.1 \mathrm{~mm}$ & $0.3 \times 0.1 \times 0.08 \mathrm{~mm}$ \\
\hline Crystal morphology & Parallelepiped & Parallelepiped \\
\hline Colour & Dark-red & Yellow \\
\hline $\begin{array}{l}\text { Theta range for data } \\
\text { collection }\end{array}$ & 1.82 to $25.00^{\circ}$ & 2.12 to $24.98^{\circ}$ \\
\hline Limiting indices & $\begin{array}{l}-15<=\mathrm{h}<=0, \\
0<=\mathrm{k}<=19, \\
-17<=1<=18\end{array}$ & $\begin{array}{l}-13<=\mathrm{h}<=0 ; \\
0<=\mathrm{k}<=17 ; \\
-22<=1<=23\end{array}$ \\
\hline $\begin{array}{c}\text { Reflections collected / } \\
\text { unique }\end{array}$ & $\begin{array}{c}6129 / 5863[\mathrm{R}(\text { int })= \\
0.0699]\end{array}$ & $\begin{array}{c}6105 / 5807[\mathrm{R}(\text { int })= \\
0.0505]\end{array}$ \\
\hline Completeness to theta & $99.0 \%(\theta=25.00)$ & $99.4 \%(\theta=24.98)$ \\
\hline Refinement method & $\begin{array}{l}\text { Full-matrix least- } \\
\text { squares on } \mathrm{F}^{2}\end{array}$ & $\begin{array}{l}\text { Full-matrix least- } \\
\text { squares on } \mathrm{F}^{2}\end{array}$ \\
\hline Data / restraints / & $5863 / 0 / 430$ & $5807 / 0 / 397$ \\
\hline
\end{tabular}




\begin{tabular}{|l|l|l|}
\hline parameters & & \\
\hline Goodness-of-fit on $\mathrm{F}^{2}$ & 0.999 & 0.912 \\
\hline $\begin{array}{l}\text { Final R indices } \\
{[\mathrm{I}>2 \text { sigma(I) }}\end{array}$ & $\mathrm{R} 1=0.0580, \mathrm{wR} 2=$ & $\mathrm{R} 1=0.0782, \mathrm{wR} 2=$ \\
0.1335 & 0.1269 \\
\hline $\mathrm{R}$ indices (all data) & $\mathrm{R} 1=0.1098, \mathrm{wR} 2=$ & $\mathrm{R} 1=0.2045, \mathrm{wR} 2=$ \\
& 0.1544 & 0.1536 \\
\hline Extinction coefficient & $0.0020(5)$ & none \\
\hline $\begin{array}{l}\text { Largest diff. peak and } \\
\text { hole }\end{array}$ & 0.913 and $-0.582 \mathrm{e} . \AA^{-3}$ & 0.433 and $-0.335 \mathrm{e} . \AA^{-3}$ \\
\hline
\end{tabular}


Figure 1

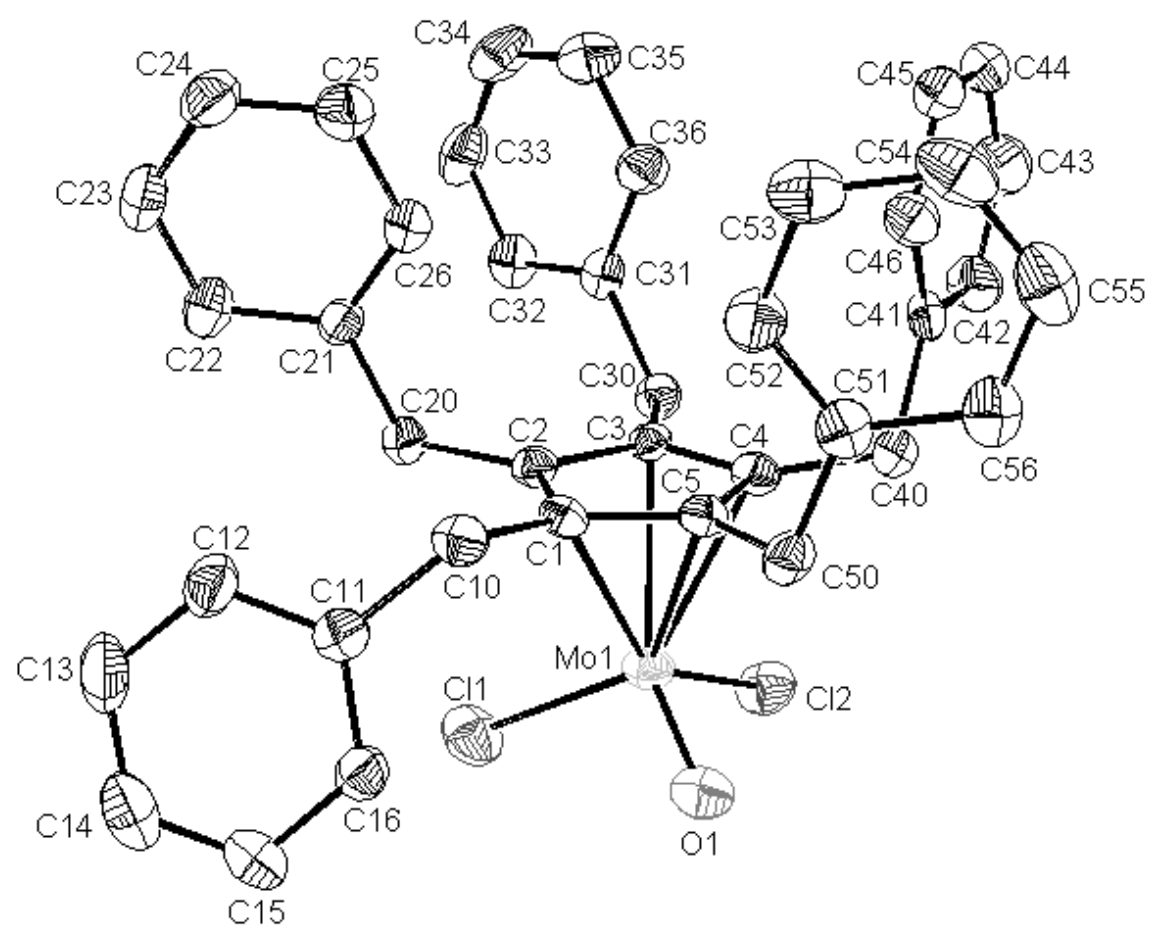


Figure 2

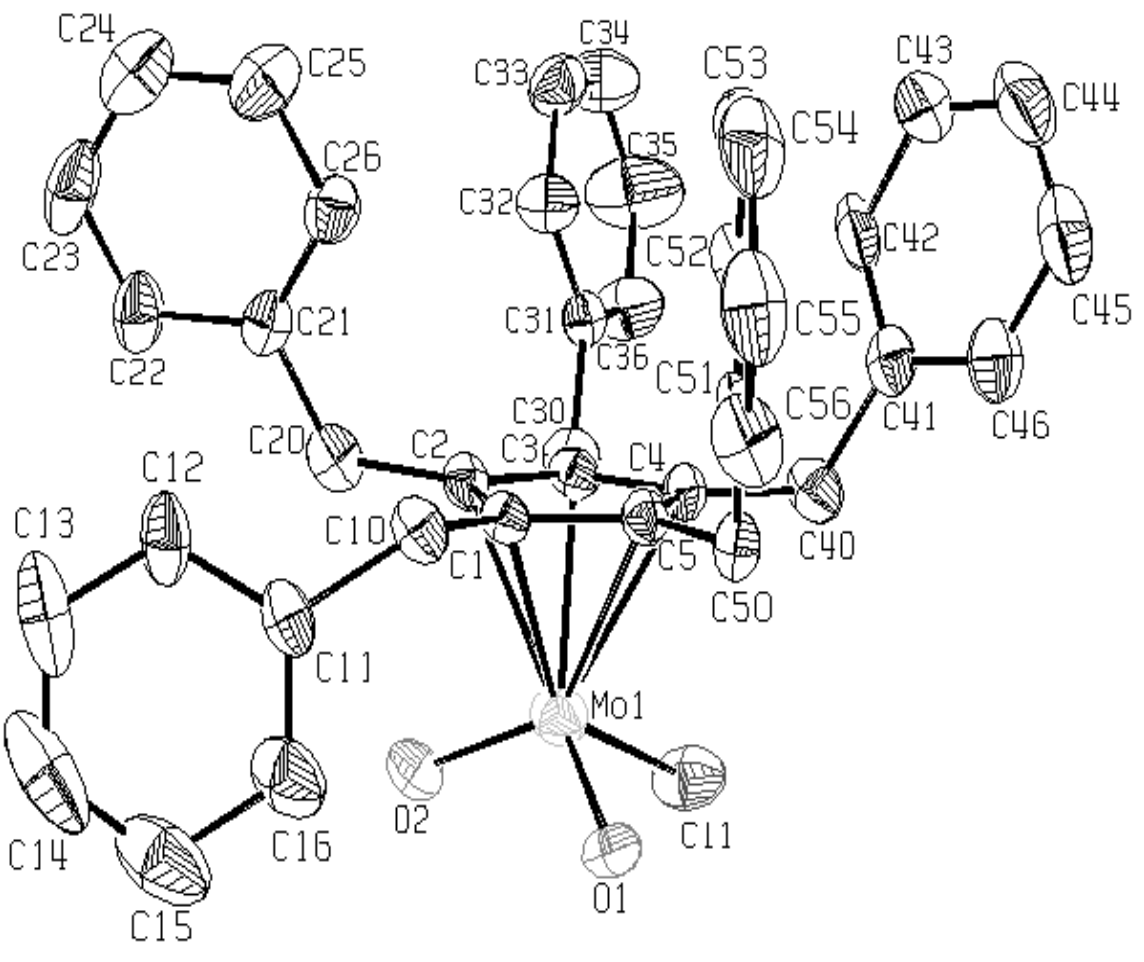


Figure 3

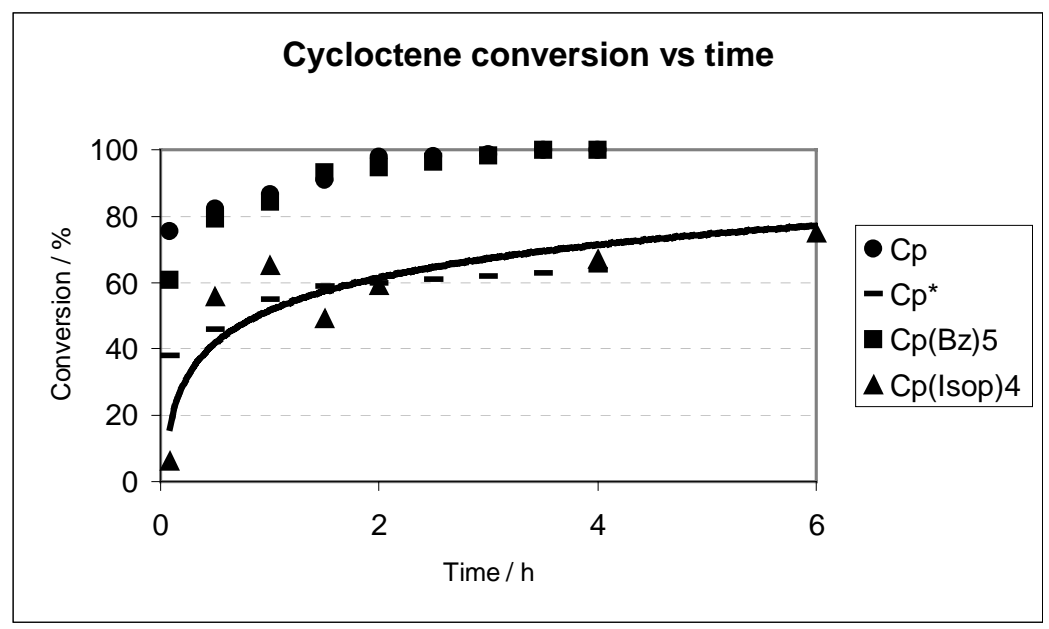


Figure 4

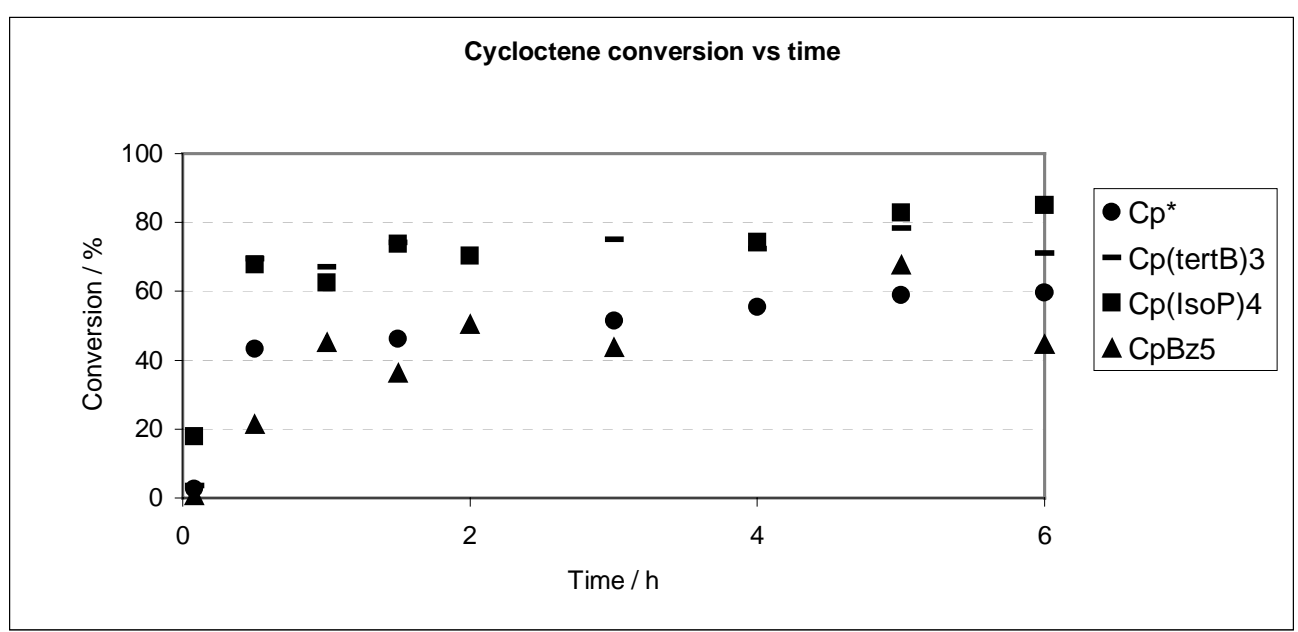

